\title{
Crop Load Overwhelms Effects of Gibberellic Acid and Ethephon on Floral Initiation in Apple
}

\author{
Tory Schmidt ${ }^{1}$ \\ Department of Horticulture and Landscape Architecture, Washington State \\ University, Pullman, WA 99164
}

\author{
Don C. Elfving \\ Department of Horticulture and Landscape Architecture, Washington State \\ University, Tree Fruit Research and Extension Center, 1100 N. Western \\ Avenue, Wenatchee, WA 98801
}

\author{
James R. McFerson \\ Washington Tree Fruit Research Commission, 1719 Springwater Avenue, \\ Wenatchee, WA 98801
}

\author{
Matthew D. Whiting \\ Department of Horticulture and Landscape Architecture, Washington State \\ University, Irrigated Agriculture Research and Extension Center, 24106 \\ North Bunn Road, Prosser, WA 99350
}

Additional index words. Malus domestica, biennial bearing, floral initiation, return bloom, 'Cameo', 'Honeycrisp', 'Fuji'

Abstract. Potential strategies against biennial bearing in apple [Malus $\times$ sylvestris $(\mathrm{L}$. Mill. var. domestica (Borkh.) Mansf.] include promotion of return bloom with an "on"year application of ethephon or inhibition of return bloom with an "off"-year application of gibberellic acid (GA), but the influence of initial crop load on the efficacy of these bioregulators is poorly understood. In 2004 and 2005, six total trials were initiated in which whole trees were manually adjusted shortly before anthesis to one of three levels of crop load $(100 \%, 50 \%, 0 \%)$ in 'Cameo', 'Honeycrisp', and 'Fuji'; $\mathbf{G A}_{4}+7$ was overlaid on trees of each crop level in four trials and ethephon in two. In all trials, initial crop load was the primary determinant of return bloom; proportional influence on flower density, fruit density, and yield was generally most pronounced at the $50 \%$ crop level. $\mathbf{G A}_{4}+7$ consistently reduced floral initiation, whereas ethephon promoted it. Flowering responses from a historically alternating 'Cameo' trial site showed greater sensitivity to ethephon and less sensitivity to $\mathbf{G A}_{4}+7$ than did responses from parallel trials established in an annually bearing 'Cameo' block, suggesting a predilection of nascent buds to a specific fate before the influence of exogenous bioregulators or gibberellins from seeds produced in developing fruit. Light crop loads and $\mathbf{G A}_{4}+7$ applications generally promoted shoot extension, whereas heavy crops and ethephon had the opposite effect.

Effective crop load management of apple is critical to the viability of commercial orchard operations. Growers routinely use a variety of strategies to produce consistent

\footnotetext{
Received for publication 10 June 2009. Accepted for publication 17 Sept. 2009.

We thank the Washington Tree Fruit Research Commission for its financial and labor support and Geoff Thornton, David Silvernail, Scott Fleming, Jim Fleming, and Kim Delay for hosting these orchard trials.

This report represents a portion of a Master's thesis submitted in December 2006 by Torrance R. Schmidt to the Department of Horticulture and Landscape Architecture of Washington State University; the author's current mailing address is c/o Washington Tree Fruit Research Commission, 1719 Springwater Avenue, Wenatchee, WA 98801.

${ }^{1}$ To whom reprint requests should be addressed; e-mail tory@treefruitresearch.com.
}

annual yields of high-quality fruit. Standard techniques such as strategic pruning, nitrogen management, and chemical thinning help maintain appropriate balance between vegetative and reproductive growth, yet many well-managed apple trees still fall into biennial bearing cycles.

The financial and horticultural costs of alternate bearing have been decried for decades in commercial apple industries around the world, including those of New York (Beach, 1903), the Pacific Northwest (Palmer and Fischer, 1937), and Australia (Bowman, 1932; Carne, 1931). Historically, research on biennial bearing focused on effective thinning techniques, but more recently, synthetic bioregulators have proven effective at either promoting or inhibiting floral initiation in apple. By applying a flowering promoter such as naphthaleneacetic acid (NAA) (Harley et al., 1958), naphthylacetamide (Harley and Regeimbal, 1959), or ethephon (Byers and Carbaugh, 1991) in the "on" year and/or a flowering inhibitor such as gibberellic acid (GA) in the "off" year (Marino and Greene, 1981), the peaks and valleys of a biennial cycle can theoretically be diminished to achieve annual yields with less variability.

Chan and Cain (1967) demonstrated the importance of fruit seeds with respect to flowering in a classic experiment on the parthenocarpic apple cultivars Ohio 3 and Spencer Seedless. Manual pollination of blossoms induced a marked reduction in flowering the next season, suggesting a direct correlation between seed development and floral initiation. Careful analyses of apple seed extracts have subsequently identified a variety of endogenous gibberellins (Ramirez, 1995) and exogenous GAs have been shown to reduce flowering in apple the season after application (Bertelsen and Tustin, 2002; McArtney, 1994; Meador and Taylor, 1987; Tromp, 1982).

The presence or absence of gibberellins clearly influences flowering in apple, but the underlying mechanisms for that relationship are not well understood. Low return bloom in poorly thinned apple trees is often blamed on floral inhibition from endogenous gibberellins synthesized in the endosperm of developing seeds (Elfving, 1996), but the systematic model of flowering in apple may involve multiple metabolic mechanisms.

Pointing to the lack of direct proof of GA export from apple seeds, Dennis and Neilsen (1999) argued for consideration of an alternative model for floral initiation in which seeds have high demand for the presumed flowering promoter, florigen; if differentiating buds are poorer sinks for florigen than surrounding fruitlets/seeds, they would be less likely to become reproductive. Using radiolabeled GA and mass spectrometry, Stephan et al. (1999) did later offer evidence of GA export from apple fruits and transport of radiolabeled exogenous GAs to surrounding pedicels and bourses (Stephan et al., 2001). They further found that 'Spencer Seedless' exhibited quantities of GA similar to those of seeded cultivars Golden Delicious and Jonica and suggested that GA may be produced in the pericarp of 'Spencer Seedless'. Despite the findings of Stephan's group, the hypothesis posited by Dennis and Neilsen may still be valid; plant hormones other than gibberellins could logically play a role in floral initiation.

Conducting a similar study to Chan and Cain's on the facultatively parthenocarpic pear (Pyrus communis L.) cultivar Williams Bon Chretien (syn. 'Bartlett'), Weinbaum et al. (2001) found that return bloom was inhibited on spurs bearing fruit, whether or not those pears contained seeds. Although this phenomenon is common in California, where the study was conducted, in other geographic regions, seeded 'Bartlett' pears are believed to be more inhibitory to floral initiation than unseeded fruit. Because of this inconsistency among genotypes in different locations, the authors suggest that "seed-derived hormonal 
inhibitors may not function consistently as the primary determinant of floral initiation" and that "broad extrapolation of Chan and Cain's results to other apple cultivars and other species may be inappropriate" (Weinbaum et al., 2001).

Callejas and Bangerth (1997) found increased levels of diffusible indoleacetic acid, an auxin, in fruits and shoot tips of 'Elstar' and 'Golden Delicious' during the period of floral initiation, especially after application of exogenous GA. The study did not report treatment effects on return bloom, but the impact of GA on transport of auxin during bud differentiation suggests a complex model of flowering involving multiple hormonal factors.

Ethylene is known to thin fruit and promote reproductive growth in many tree fruit species (Greene, 1996), but it is unclear whether increased floral initiation is directly controlled by the gas or associated with increased plant resources resulting from reduced vegetative growth (Walsh and Kender, 1982). Regardless of specific mechanisms, ethylene-inducing bioregulators such as ethephon and NAA are widely used by commercial orchardists to promote return bloom.

Ethephon can also be a useful tool when increased florigenesis is desired without increased thinning of the current season's crop; Ferree and Schmid (2000) demonstrated these effects in 'Fuji' with weekly applications at $200 \mathrm{mg} \cdot \mathrm{L}^{-1}$ starting at $10-\mathrm{mm}$ fruitlet size for durations of 4 or 6 weeks. Byers (1993) found that $1200 \mathrm{mg} \cdot \mathrm{L}^{-1}$ of ethephon reduced current-season fruit size and trunk cross-sectional area but increased return bloom of 'Starkrimson Delicious' when applied at 26, 61, and $103 \mathrm{~d}$ after full bloom. Return bloom has also been improved by applications of ethephon around June drop (35 to $50 \mathrm{~d}$ after full bloom) on 'Nured Delicious' (Byers and Carbaugh, 1991), 'McIntosh', and 'Melba' (Karaszewska et al., 1986) and 'Golden Delicious' and 'Cox's Orange Pippin' (Luckwill and Child, 1978). The Crop Protection Guide for Tree Fruits in Washington (Washington State University, 2009) recommends application of $300 \mathrm{mg} \cdot \mathrm{L}^{-1}$ ethephon after June drop has begun to promote flowering in bearing apple trees without excessive thinning of the current crop.

Considerable work has been published regarding effective isomers, rates, and timings for using GA and ethephon to manage bloom in apple, but little has been reported regarding the influence of initial crop on the efficacy of these bioregulators. Greene (1989) sprayed GA in split applications on 'Empire' trees of varying crop load. He found that $\mathrm{GA}_{4+7}$ decreased return bloom on decropped trees, increased return bloom on fully cropped trees, and had little effect on trees with moderate crop loads, results that do little to clarify the role of gibberellins in floral initiation in apple. If one presumes that a tree with a light crop has a different hormone profile than one with a heavy crop, then it is reasonable to expect that the response to exogenous bioregulators might be different between those trees. This article reports on a series of experiments that further consider the influence of initial crop load on the efficacy of GA and ethephon applications in apple cultivars prone to biennial bearing.

\section{Materials and Methods}

Experimental design. All field trials for this study were conducted in commercial apple orchards in several growing districts of Washington State. Aside from elimination of bioregulator programs that affect flower initiation, standard orchard management strategies were followed by grower-cooperators. Each trial used a randomized complete block design with six replicates, except for two 2004 trials on 'Cameo' in Tonasket, which used five replicates as a result of field limitations. In all cases, whole individual trees served both as experimental and sampling units. To isolate treatments, at least one buffer row was maintained between rows receiving treatment. In addition, a minimum of $3 \mathrm{~m}$ (two to five trees) separation between treated trees was maintained within the row for all trials.

Data were analyzed with the Statistical Analysis System (SAS) of the SAS Institute, Cary, NC. Means were separated with the general linear model using Tukey's Studentized range test at 0.05 by one-way or factorial analysis of variance (Proc GLM). Where fixed-effect variables allowed regression analysis, the General Linear Models procedure of SAS was used to evaluate the homogeneity of slopes, curvatures, and intercepts of the regressions on crop load, bioregulator concentration, or application timing, as appropriate. Only significant findings are included in this report.

Treatments. For each of the six trials in this study, three levels of crop load were established before application of growth regulators. Trees representative of the overall bloom density of their respective orchards were selected as experimental units with minimal variation between individual trees. At the late pink or "balloon" stage of blossom development, all flowers were pruned from every cluster in one-third of treatment trees ( $0 \%$ crop load), all flowers were pruned from alternating clusters in one-third of treatment trees $(50 \%$ crop load), or flowers were left untouched $(100 \%$ crop load) in the remaining one-third of treatment trees. Flower pruning was achieved by clipping flower pedicels with hand blossom shears while preserving spur buds and leaves.

The commercial $\mathrm{GA}_{4}+7$ formulation "ProVide" (Valent Biosciences, Libertyville, IL) was used in four trials, and in the remaining two trials, ethephon was sprayed as "Ethrel" (Bayer CropScience, Research Triangle Park, NC). Applications were timed according to phenologic fruit development as determined by the mean diameter of king apples of 30 randomly selected fruit clusters measured with digital calipers (Mitutoyo Corp., Kawasaki, Japan) in the respective trial blocks. Applications were made by handgun with a 25-gallon 'Nifty' power sprayer (Rears Manufacturing, Eugene, OR) adjusted to a fine mist at $200 \mathrm{lbs} / \mathrm{in}^{2}$ pressure. Whole trees were sprayed until all visible foliage was wet, but not to the point of dripping from more than $10 \%$ of all leaves. No adjuvants were used for any spray.

2004 trials. Two trials were established in a severely alternating 7-year-old 'Cameo'/M.9 Budagovsky 9 (B.9) orchard near Tonasket, WA (long. $48.8^{\circ} \mathrm{N}$, lat. $119.4^{\circ} \mathrm{W}$ ) in trees with extremely heavy bloom. Trees were planted $1 \mathrm{~m} \times 3.5 \mathrm{~m}$ and trained to a threewire vertical trellis in a spindle system. In one trial, $400 \mathrm{mg} \cdot \mathrm{L}^{-1} \mathrm{GA}_{4}+7$ was sprayed on each crop level $(0 \%, 50 \%, 100 \%)$ at petal fall, $10-\mathrm{mm}$ fruitlet size, or $20-\mathrm{mm}$ fruitlet size. Unsprayed control treatments were maintained at each crop level. In an adjacent trial, 300, 600, or $900 \mathrm{mg} \cdot \mathrm{L}^{-1}$ ethephon was sprayed on trees of each crop level at $45 \mathrm{~d}$ after full bloom. Again, unsprayed controls were preserved for each crop level.

In a third 2004 trial, heavy-blooming 5-year-old 'Honeycrisp'/M.9 EMLA (EMLA.9) were likewise adjusted for crop level near Wiley City, WA (long. $46.5^{\circ} \mathrm{N}$, lat. $120.7^{\circ} \mathrm{W}$ ). Trees in the trial block were planted $2 \mathrm{~m} \times$ $3.5 \mathrm{~m}$ and trained to a vertical axis system on a two-wire vertical trellis. Trees at each crop level were either left unsprayed or sprayed with $300 \mathrm{mg} \cdot \mathrm{L}^{-1} \mathrm{GA}_{4}+7$ at $10-\mathrm{mm}$ fruitlet size.

2005 trials. Protocols identical to the Tonasket 'Cameo' trials described previously were carried out in a relatively annually bearing, moderate-blooming 9-year-old 'Cameo'/ M.9 Nicolai 29 (Nic.29) orchard near Quincy, WA (long. $47.3^{\circ} \mathrm{N}$, lat. $119.7^{\circ} \mathrm{W}$ ). Trees in this block were spaced $1.5 \mathrm{~m} \times 3.5 \mathrm{~m}$ and trained to a five-wire V-trellis.

A third trial was conducted on heavyblooming 12-year-old 'Fuji'/M.26 (M.26) near Othello, WA (long. $46.8^{\circ} \mathrm{N}$, lat. $119.5^{\circ} \mathrm{W}$ ) using a protocol identical to the Wiley City 'Honeycrisp' trial described previously. Trees in this block were trained to a Lincoln canopy system with $1 \mathrm{~m} \times 4$-m spacing.

Data collection. After manual crop adjustment, trunk circumferences and whole tree bloom counts were recorded. Fruit set was evaluated after June drop and whole tree fruit counts and yields were recorded at commercial harvest in September and October. Twenty fruit samples were taken from each bearing tree for standard harvest quality analyses, including indices of fruit weight, length, diameter, color, firmness, sugars, and acid content. Fruit finish was graded visually for sunburn and six classes of russet indicating location and size of surface blemishes. After completion of commercial harvest, 10 vertical shoots per tree were measured for the current season's growth, long after terminal buds had set. In the spring after treatment, trunk circumferences were again measured and flower clusters were counted on whole trees at the pink stage of blossom development. Like in the year of treatment, fruit counts and yields were again recorded during commercial harvest in fall. 


\section{Results and Discussion}

2004 'Cameo' gibberellic acid trial. This trial was initiated in the on-year of a block in a severe biennial cycle. According to the grower, yields swung by a factor of three to four times between light and heavy years. Occasional trees in the block were in the offyear of their cycles in 2004 but were excluded from the trial. Regression analyses revealed that crop load was associated with powerful linear and quadratic reductions of bloom density, fruit density, and yield in the year after treatment (Table 1). The application of $\mathrm{GA}_{4}+7$ significantly decreased those same parameters with $10-\mathrm{mm}$ and $20-\mathrm{mm}$ timings showing the greatest treatment effects. Interactivity between crop load and application timing was largely insignificant, except in the case of 2005 yields, in which petal fall, $10-\mathrm{mm}$ spray, and $20-\mathrm{mm}$ spray all showed significant curvilinear effects (Table 2). Shoot growth was not impacted by any treatment and analyses of fruit quality at harvest did not produce consistent or significant results (data not shown).

Unsprayed trees allowed to carry full crops in 2004 generated only 0.4 flower clusters $/ \mathrm{cm}^{2}$ trunk cross-sectional area (TCSA) in the following spring; application of $\mathrm{GA}_{4}+7$ to trees of that same crop level essentially eliminated the entire 2005 crop. At the opposite end of the spectrum, unsprayed trees whose entire crop was manually eliminated in 2004 produced 5.8 flower clusters $/ \mathrm{cm}^{2}$ TCSA in 2005; application of $\mathrm{GA}_{4}+7$ in 2004 to trees of that crop level diminished return bloom by $5 \%$ to $30 \%$. Unsprayed trees with 2004 crops, which were reduced by half, generated 1.6 flower clusters $/ \mathrm{cm}^{2}$ TCSA in 2005. Trees of this moderate 50\% 2004 crop load showed the greatest relative response to $\mathrm{GA}_{4+7}$, because 2005 cropping was virtually eliminated regardless of timing. Results from this trial imply that application of exogenous GA can do little to affect flowering of 'Cameo' with extremely heavy or extremely light crop loads but that it is able to inhibit floral initiation in more moderate cropping situations; before drawing firm conclusions, however, these results should be viewed in light of data from the following trial, which followed the same protocol, but in annually cropping 'Cameo'.

2005 'Cameo' gibberellic acid trial. 'Cameo' trials were relocated in 2005 to another orchard with relatively no background alternation. The grower reported year-to-year swings in yields of no greater than $10 \%$ to $15 \%$. Using a popular industry phrase, trees in this block were "settled down" as indicated by the $9 \mathrm{~cm}$ of mean terminal growth in untreated control trees (Table 3) as compared with $32-\mathrm{cm}$ growth in the 2004 'Cameo' trial block (Table 1); trees appeared healthy and no symptoms of mineral deficiencies contributing to limited shoot growth were observed. Like in the earlier 'Cameo' GA trial, crop load produced significant linear and quadratic reductions on all measures of cropping in the season after treatment

Table 1. Effects of spray timing and crop load on response to $400 \mathrm{mg} / \mathrm{L} \mathrm{GA}_{4}+7$ application in 2004 in severely alternating 'Cameo'/B.9 apple trees. ${ }^{\text {' }}$

\begin{tabular}{|c|c|c|c|c|c|}
\hline Treatment & $\begin{array}{l}2004 \text { shoot } \\
\text { extension } \\
(\mathrm{cm})^{\mathrm{y}}\end{array}$ & $\begin{array}{c}2004 \\
\text { yield/TCSA } \\
\left(\mathrm{kg} \cdot \mathrm{cm}^{-2}\right)\end{array}$ & $\begin{array}{c}2005 \\
\text { bloom/TCSA } \\
\text { (flower clusters } / \mathrm{cm}^{2} \text { ) }\end{array}$ & $\begin{array}{l}2005 \text { harvested } \\
\text { fruits/TCSA } \\
\left(\text { fruit } / \mathrm{cm}^{2}\right)\end{array}$ & $\begin{array}{c}2005 \\
\text { yield/TCSA } \\
\left(\mathrm{kg} \cdot \mathrm{cm}^{-2}\right)\end{array}$ \\
\hline Control, 100 & 32.1 & 1.6 & 0.4 & 0.9 & 0.2 \\
\hline Control, 50 & 33.0 & 1.4 & 1.6 & 4.1 & 0.8 \\
\hline Control, 0 & 35.3 & 0.0 & 5.8 & 7.4 & 1.0 \\
\hline $\mathrm{PF}, 100$ & 34.8 & 1.1 & 0.1 & 0.4 & 0.1 \\
\hline $\mathrm{PF}, 50$ & 33.0 & 1.0 & 0.2 & 0.8 & 0.2 \\
\hline PF, 0 & 33.5 & 0.0 & 5.5 & 8.6 & 1.1 \\
\hline $10 \mathrm{~mm}, 100$ & 38.5 & 1.1 & 0.0 & 0.0 & 0.0 \\
\hline $10 \mathrm{~mm}, 50$ & 34.4 & 1.1 & 0.1 & 0.4 & 0.1 \\
\hline $10 \mathrm{~mm}, 0$ & 39.2 & 0.0 & 4.2 & 8.3 & 1.0 \\
\hline $20 \mathrm{~mm}, 100$ & 30.9 & 1.2 & 0.0 & 0.0 & 0.0 \\
\hline $20 \mathrm{~mm}, 50$ & 31.1 & 1.3 & 0.1 & 0.0 & 0.0 \\
\hline $20 \mathrm{~mm}, 0$ & 35.6 & 0.0 & 4.1 & 6.2 & 0.8 \\
\hline \multicolumn{6}{|l|}{ Significance } \\
\hline \multicolumn{6}{|c|}{$\mathrm{GA}_{4}+7$ timing ${ }^{\mathrm{w}}$} \\
\hline None & $33.5 \mathrm{NS}$ & $1.0 \mathrm{a}$ & $2.6 \mathrm{a}$ & $4.1 \mathrm{a}$ & $0.7 \mathrm{a}$ \\
\hline Petal fall & 34.6 & $0.7 \mathrm{~b}$ & $2.0 \mathrm{ab}$ & $3.5 \mathrm{ab}$ & $0.5 \mathrm{~b}$ \\
\hline $10 \mathrm{~mm}$ & 37.4 & $0.7 \mathrm{~b}$ & $1.5 \mathrm{~b}$ & $2.9 \mathrm{ab}$ & $0.4 \mathrm{bc}$ \\
\hline $20 \mathrm{~mm}$ & 33.5 & $0.8 \mathrm{ab}$ & $1.5 \mathrm{~b}$ & $2.2 \mathrm{~b}$ & $0.3 \mathrm{c}$ \\
\hline$P$ values & 0.32 & 0.002 & 0.02 & 0.0009 & $<0.0001$ \\
\hline \multicolumn{6}{|l|}{ Crop load ${ }^{\mathrm{v}}$} \\
\hline $\mathrm{L}$ & NS & $* * * *$ & $* * * *$ & $* * * *$ & $* * * *$ \\
\hline Q & NS & $* * * *$ & $* * * *$ & $* * * *$ & $* * * *$ \\
\hline \multicolumn{6}{|c|}{ Crop load $* \mathrm{GA}_{4+7}$ timing interaction ${ }^{v}$} \\
\hline $\mathrm{L}$ & NS & NS & NS & NS & See Table 2 \\
\hline Q & NS & NS & NS & $* *$ & See Table 2 \\
\hline Model $r^{2}$ & 0.33 & 0.92 & 0.86 & 0.93 & 0.93 \\
\hline
\end{tabular}

${ }^{z}$ Treatments are listed by phenological application timing [unsprayed controls, petal fall (PF), 10-mm fruit size, or 20-mm fruit size] and manually adjusted crop level (100\%, 50\%, or $0 \%$ crop).

${ }^{\mathrm{y}}$ Mean of 10 terminal shoots per tree.

${ }^{x}$ Trunk cross-sectional area.

"Analysis by factorial analysis of variance and means separation by Tukey's Studentized range test $(P=0.05)$. Means followed by the same letter are not statistically significant within a column.

${ }^{\mathrm{v}} \mathrm{L}=$ linear effect; $\mathrm{Q}=$ second-order (quadratic) effect.

NS, $* *, * * * *$ Nonsignificant or significant at $P=0.01$ or 0.0001 , respectively.

(Table 3). Application of $\mathrm{GA}_{4}+7$ significantly diminished those same parameters at all timings, including petal fall, which had yielded results slightly inferior to those of the later timings in the 2004 trial. No interactive effects between initial crop load and spray timing were detected in this trial. Unlike the previous year, shoot growth was increased $29 \%$ to $138 \%$ by $\mathrm{GA}_{4}+7$ with the strongest effects resulting from earlier timings. Harvest fruit quality analysis revealed no significant treatment effects (data not shown).

Although the inhibitory effects of $\mathrm{GA}_{4+7}$ were most clear at the $50 \%$ crop level in the 2004 'Cameo' GA trial, all three crop levels demonstrated clear reductions in flowering, fruit density, and yield in the 2005 trial. Unsprayed trees at the $100 \%, 50 \%$, and $0 \%$ crop levels produced $6.1,6.5$, and 13.7 flower clusters $/ \mathrm{cm}^{2}$ TCSA in 2006, respectively. Application of $\mathrm{GA}_{4+7}$ reduced 2006 flowering $78 \%$ to $89 \%$ in trees with full crops in $2005,92 \%$ to $97 \%$ in trees with $50 \%$ crops in 2005 , and $30 \%$ to $61 \%$ in trees with no crop in 2005. Like with shoot growth, the strongest treatment effects were consistently produced by petal fall sprays. Like the 2004 trial, the greatest efficacy of $\mathrm{GA}_{4}+7$ was seen at the $50 \%$ crop level, but in this more annual 'Cameo' block, $\mathrm{GA}_{4+7}$ also strongly inhibited flowering at the two extreme crop levels.
Table 2. Interactive effects of spray timing and crop load related to 2005 yield $/ \mathrm{TCSA}^{\mathrm{z}}\left(\mathrm{kg} / \mathrm{cm}^{2}\right)$ response to $400 \mathrm{mg} / \mathrm{L} \mathrm{GA}_{4}+7$ application in 2004 in severely alternating 'Cameo'/B.9 apple trees.

\begin{tabular}{lc}
\hline $\mathrm{GA}_{4}+7$ timing & $\begin{array}{c}\text { Regression } \\
\text { significance }\end{array}$ \\
\hline Control & $* * * *$ \\
$\mathrm{~L}$ & $\mathrm{NS}$ \\
$\mathrm{Q}$ & 0.90 \\
Model $r^{2}$ & \\
Petal fall & $* * * *$ \\
$\mathrm{~L}$ & $* * *$ \\
$\mathrm{Q}$ & 0.97 \\
Model $r^{2}$ & \\
10 mm & $* * *$ \\
$\mathrm{~L}$ & $* *$ \\
$\mathrm{Q}$ & 0.93 \\
Model $r^{2}$ & \\
20 mm & $* * *$ \\
$\mathrm{~L}$ & $* *$ \\
$\mathrm{Q}$ & 0.94 \\
Model $r^{2}$ & \\
\hline
\end{tabular}

${ }^{\text {zTrunk cross-sectional area. }}$

${ }^{\mathrm{y}} \mathrm{L}=$ linear effect; $\mathrm{Q}=$ second-order (quadratic) effect.

$\mathrm{NS}, * *, * * *, * * * *$ Nonsignificant or significant at $P=0.01,0.001$, or 0.0001 , respectively.

On removal of all flowers before anthesis, it is reasonable to assume that a major source of endogenous gibberellins, i.e., juvenile 
seeds, has been eliminated, which should, in turn, make an apple tree more susceptible to the effects of exogenously applied GA. In other words, with no significant internal hormonal restraint, decropped trees should produce a massive return bloom and be relatively sensitive to the effects of an external floral inhibitor. In both 'Cameo' GA trials, however, the greatest proportional responses were manifested in trees with only half of their flowers removed, implying the presence/ absence of seed-derived gibberellins does not exclusively account for the fate of undifferentiated apple buds. Furthermore, regularly cropping 'Cameo' showed greater proportional sensitivity to GA than did severely biennial 'Cameo', suggesting that some phenomenon associated with alternation within the latter had, to some degree, conferred physiological momentum of nascent buds toward a fate unaffected by experimental manipulation of endogenous or exogenous gibberellins. An alternative explanation for reduced flowering in the annually cropping 'Cameo' trees relates to increased shoot growth resulting from exogenous GA applications; endogenous GA produced in more vigorous shoots could have inhibited floral initiation in concurrently differentiating buds.

2004 'Honeycrisp' gibberellic acid trial. Trial designs for this and the 2005 'Fuji' GA trials were simplified versions of the 'Cameo' GA trials; crop loads were still manually adjusted to $100 \%, 50 \%$, or $0 \%$ levels, but only one timing of GA application, i.e., $10 \mathrm{~mm}$, was imposed in a factorial fashion on those crop levels. Background alternation in this block was moderate with $\approx 30 \%$ swings in annual yields. Crop load had significant negative linear and quadratic effects on 2005 floral density, fruit density, and yield (Table 4). Application of $\mathrm{GA}_{4}+7$ did not significantly affect 2004 shoot growth or 2005 flower density, but did decrease fruit density and yield by $30 \%$. Decropped trees demonstrated greater 2004 shoot growth than fully cropped trees, presumably as a result of increased carbohydrates and nutrients partitioned to shoot apices. Interactive effects of initial crop level and GA had linear and quadratic significance relative to 2005 floral density, fruit density, and yield. Fruit quality in 2004 was unaffected by any treatment (data not shown).

The relative efficacy of $\mathrm{GA}_{4}+7$ in this moderately biennial block mirrors that of the severely alternative 2004 'Cameo' GA trial; namely, application of $\mathrm{GA}_{4}+7$ to trees with $100 \%$ or $0 \%$ crop levels did little to influence return bloom but reduced 2005 floral density in trees with $50 \%$ crop levels in 2004 by $65 \%$. Again, the relative lack of GA sensitivity in decropped trees suggests that undifferentiated buds in those trees are compelled to flower by signals aside from the influence of seed-derived or exogenous GA.

2005 'Fuji' gibberellic acid trial. Consistent annual production in this block indicates no significant biennial bearing habits with no greater than $10 \%$ swings in year-to-year yields. Adjusted crop level in 2005 produced
Table 3. Effects of spray timing and crop load on response to $400 \mathrm{mg} / \mathrm{L} \mathrm{GA}_{4+7}$ application in 2005 in mildly alternating 'Cameo'/Nic.29 apple trees. ${ }^{\mathrm{C}}$

\begin{tabular}{|c|c|c|c|c|c|}
\hline Treatment & $\begin{array}{l}2005 \text { shoot } \\
\text { extension } \\
(\mathrm{cm})^{\mathrm{y}}\end{array}$ & $\begin{array}{c}2005 \\
\text { yield } / \mathrm{TCSA}^{\mathrm{x}} \\
\left(\mathrm{kg} \cdot \mathrm{cm}^{-2}\right)\end{array}$ & $\begin{array}{c}2006 \\
\text { bloom } / \mathrm{TCSA} \\
\text { (flower clusters } / \mathrm{cm}^{2} \text { ) }\end{array}$ & $\begin{array}{c}2006 \text { harvested } \\
\text { fruits/TCSA } \\
\left.\text { (fruit } / \mathrm{cm}^{2}\right)\end{array}$ & $\begin{array}{c}2006 \\
\text { yield } / \mathrm{TCSA}^{\mathrm{x}} \\
\left(\mathrm{kg} \cdot \mathrm{cm}^{-2}\right)\end{array}$ \\
\hline Control, 100 & 8.8 & 2.4 & 6.1 & 4.8 & 1.0 \\
\hline Control, 50 & 8.5 & 1.2 & 6.5 & 4.9 & 1.1 \\
\hline Control, 0 & 8.0 & 0.0 & 13.7 & 8.6 & 1.7 \\
\hline PF, 100 & 18.3 & 1.0 & 0.7 & 0.8 & 0.2 \\
\hline $\mathrm{PF}, 50$ & 20.8 & 0.9 & 0.2 & 0.3 & 0.1 \\
\hline $\mathrm{PF}, 0$ & 21.1 & 0.0 & 5.3 & 5.8 & 1.2 \\
\hline $10 \mathrm{~mm}, 100$ & 13.5 & 1.1 & 1.4 & 1.2 & 0.3 \\
\hline $10 \mathrm{~mm}, 50$ & 14.8 & 0.8 & 0.5 & 0.7 & 0.2 \\
\hline $10 \mathrm{~mm}, 0$ & 15.5 & 0.0 & 7.5 & 5.9 & 1.3 \\
\hline $20 \mathrm{~mm}, 100$ & 10.2 & 1.1 & 1.4 & 1.7 & 0.4 \\
\hline $20 \mathrm{~mm}, 50$ & 11.6 & 1.1 & 0.5 & 0.6 & 0.1 \\
\hline $20 \mathrm{~mm}, 0$ & 10.6 & 0.0 & 9.6 & 8.2 & 1.6 \\
\hline
\end{tabular}

Significance

$\begin{array}{llllll}\mathrm{GA}_{4}+7 \text { timing }^{\mathrm{w}} & & & & \\ \text { None } & 8.4 \mathrm{c} & 1.2 \mathrm{NS} & 8.8 \mathrm{a} & 6.1 \mathrm{a} & 1.3 \mathrm{a} \\ \text { Petal fall } & 20.0 \mathrm{a} & 0.6 & 2.1 \mathrm{~b} & 2.3 \mathrm{~b} & 0.5 \mathrm{~b} \\ 10 \mathrm{~mm} & 14.6 \mathrm{~b} & 0.6 & 3.1 \mathrm{~b} & 2.6 \mathrm{~b} & 0.6 \mathrm{~b} \\ 20 \mathrm{~mm} & 10.8 \mathrm{c} & 0.7 & 3.8 \mathrm{~b} & 3.5 \mathrm{~b} & 0.7 \mathrm{~b} \\ P \text { values } & <0.0001 & 0.06 & <0.0001 & <0.0001 & <0.0001 \\ \text { Crop load } & & & & * * * * & * * * \\ \text { L } & \text { NS } & * * * * & * * * & * * * & * * * \\ \text { Q } & \text { NS } & 0.08 & * * * & 0.84 & 0.82 \\ \text { Model } r^{2} & 0.78 & 0.58 & 0.84 & & *\end{array}$

${ }^{\mathrm{z}}$ Treatments are listed by phenological application timing [unsprayed controls, petal fall (PF), 10-mm fruit size, or $20-\mathrm{mm}$ fruit size] and manually adjusted crop level $(100 \%, 50 \%$, or $0 \% \mathrm{crop})$. All interactive terms not significantly different $(P=0.05)$.

${ }^{y}$ Mean of 10 terminal shoots per tree.

xTrunk cross-sectional area.

wAnalysis by factorial analysis of variance and means separation by Tukey's Studentized range test $(P=$ 0.05 ). Means followed by the same letter are not statistically significant within a column.

${ }^{\vee} \mathrm{L}=$ linear effect; $\mathrm{Q}=$ second-order (quadratic) effect.

Ns, ****Nonsignificant or significant at $P=0.0001$, respectively.

Table 4. Effects of spray and crop load on response to $300 \mathrm{mg} / \mathrm{L} \mathrm{GA}_{4+7}$ application at $10-\mathrm{mm}$ fruitlet size in 2004 on 'Honeycrisp'/EMLA.9 apple trees. ${ }^{z}$

\begin{tabular}{|c|c|c|c|c|c|}
\hline Treatment & $\begin{array}{l}2004 \text { shoot } \\
\text { extension } \\
(\mathrm{cm})^{\mathrm{y}}\end{array}$ & $\begin{array}{c}2004 \\
\text { yield/TCSA } \\
\left(\mathrm{kg} \cdot \mathrm{cm}^{-2}\right)\end{array}$ & $\begin{array}{c}2005 \\
\text { bloom/TCSA } \\
\text { (flower clusters } / \mathrm{cm}^{2} \text { ) }\end{array}$ & $\begin{array}{c}2005 \text { harvested } \\
\text { fruits } / \mathrm{TCSA} \\
\left(\text { fruit } / \mathrm{cm}^{2}\right)\end{array}$ & $\begin{array}{c}2005 \\
\text { yield/TCSA } \\
\left(\mathrm{kg} \cdot \mathrm{cm}^{-2}\right)\end{array}$ \\
\hline Unsprayed, 100 & 20.6 & 1.5 & 0.4 & 1.2 & 0.3 \\
\hline Unsprayed, 50 & 19.6 & 1.3 & 4.9 & 6.6 & 1.5 \\
\hline Unsprayed, 0 & 29.1 & 0.0 & 12.7 & 14.6 & 2.3 \\
\hline Sprayed, 100 & 21.3 & 1.4 & 0.1 & 0.4 & 0.1 \\
\hline Sprayed, 50 & 23.7 & 1.4 & 0.7 & 1.9 & 0.5 \\
\hline Sprayed, 0 & 29.6 & 0.0 & 13.2 & 14.3 & 2.1 \\
\hline \multicolumn{6}{|l|}{ Significance } \\
\hline \multicolumn{6}{|l|}{$\mathrm{GA}_{4}+7^{\mathrm{w}}$} \\
\hline Unsprayed & $23.1 \mathrm{NS}$ & $0.9 \mathrm{NS}$ & $6.0 \mathrm{NS}$ & $2.9 \mathrm{a}$ & $1.3 \mathrm{a}$ \\
\hline Sprayed & 24.9 & 0.9 & 4.7 & $2.0 \mathrm{~b}$ & $0.9 \mathrm{~b}$ \\
\hline$P$ values & 0.29 & 0.68 & 0.14 & 0.0002 & $<0.0001$ \\
\hline \multicolumn{6}{|l|}{ Crop load ${ }^{\mathrm{v}}$} \\
\hline $\mathrm{L}$ & $* *$ & $* * * *$ & $* * * *$ & $* * * *$ & $* * * *$ \\
\hline $\mathrm{Q}$ & 0.06 & $* * * *$ & $* * *$ & $* * * *$ & $*$ \\
\hline \multicolumn{6}{|c|}{ Crop load $* \mathrm{GA}_{4+7}$ interaction $^{\mathrm{v}}$} \\
\hline $\mathrm{L}$ & NS & NS & $*$ & $* * * *$ & $* * *$ \\
\hline Q & NS & NS & $*$ & $* * * *$ & $* * *$ \\
\hline Model $r^{2}$ & 0.54 & 0.93 & 0.88 & 0.97 & 0.95 \\
\hline
\end{tabular}

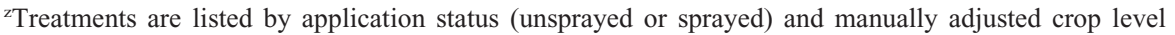
(100\%, 50\%, or $0 \%$ crop).

${ }^{\mathrm{y}}$ Mean of 10 terminal shoots per tree.

${ }^{\mathrm{x}}$ Trunk cross-sectional area.

"Analysis by factorial anaysis of variance and means separation by Tukey's Studentized range test $(P=$ 0.05). Means followed by the same letter are not statistically significant within a column.

${ }^{\mathrm{v}} \mathrm{L}=$ linear effect; $\mathrm{Q}=$ second-order (quadratic) effect.

$\mathrm{NS}, *, * *, * * *, * * * *$ Nonsignificant or significant at $P=0.05,0.01,0.001$, or 0.0001 , respectively. 
linear decreases in flowering density, fruit density, and yield in 2006 (Table 5). Application of $\mathrm{GA}_{4}+7$ increased shoot extension $32 \%$ and decreased 2006 return bloom, fruit density, and yield by $88 \%, 80 \%$, and $67 \%$, respectively. Overall values for the latter two parameters were low as a result of poor pollination and fruit set in the entire block. Like in the relatively annual 2005 'Cameo' GA trial, no significant interaction between adjusted crop level and $\mathrm{GA}_{4+7}$ was observed. This lack of interactivity again suggests that annually cropped apple trees are more responsive to GA than are trees in alternation. Fruit quality analyses yielded no significant results (data not shown).

2004 'Cameo' ethephon trial. This trial was established in the same severely alternating block used for the 2004 GA trial. Trial designs were identical with respect to crop load adjustment, but in contrast to attempting to inhibit floral initiation with exogenous GA, ethephon was applied at four concentrations in an effort to promote flowering of trees at each crop level. Multiple regression analyses revealed that 2004 crop load was negatively correlated with 2005 flower density, fruit density, and yield in a linear fashion as well as in a curvilinear fashion for 2005 yield (Table 6). Increasing ethephon concentration inhibited 2004 shoot extension and promoted 2005 return bloom, flower density, and yield; no second-order effects of ethephon were observed, and interactive effects of crop load and ethephon were generally insignificant. Harvest fruit quality analyses were unremarkable (data not shown).

Unsprayed trees carrying a full crop in 2004 produced only 0.2 flower clusters $/ \mathrm{cm}^{2}$ TCSA in 2005; flowering density was increased to $0.7,1.7$, and 1.8 flower clusters/ $\mathrm{cm}^{2}$ TCSA with application of 300,600 , and $900 \mathrm{mg} \cdot \mathrm{L}^{-1}$ ethephon, respectively. Unsprayed trees whose 2004 crop was entirely removed generated 7.1 flower clusters $/ \mathrm{cm}^{2}$ TCSA in 2005, but no concentration of ethephon sprayed to decropped trees substantially increased flowering. Like with all four GA trials, the greatest relative response to ethephon was found in trees at the $50 \%$ crop level. Unsprayed trees of this category produced 1.7 flower clusters $/ \mathrm{cm}^{2}$ TCSA, and application of 300,600 , and $900 \mathrm{mg} \cdot \mathrm{L}^{-1}$ ethephon increased 2005 floral density $65 \%, 159 \%$, and $212 \%$, respectively.

2005 'Cameo' ethephon trial. The same annually bearing block used in the 2005 'Cameo' GA trial was used for this experiment. Crop load exerted linear diminishment of 2006 flower density, fruit density, and yield, but not 2005 shoot extension (Table 7). Ethephon showed no direct or interactive treatment effects. Analyses of 2005 harvest fruit quality revealed no differences between treatments (data not shown).

Baseline levels of flowering were much higher in this trial than the 2004 'Cameo' ethephon trial (6.3 versus 0.2 flower clusters/ $\mathrm{cm}^{2}$ TCSA), sharpening the contrast between the two trial blocks. More pronounced treatment effects resulting from ethephon and

Table 5. Effects of spray and crop load on response to $300 \mathrm{mg} / \mathrm{L} \mathrm{GA}_{4+7}$ application at $10-\mathrm{mm}$ fruitlet size in 2005 on 'Fuji'/M.26 apple trees. ${ }^{z}$

\begin{tabular}{|c|c|c|c|c|c|}
\hline Treatment & $\begin{array}{l}2005 \text { shoot } \\
\text { extension } \\
(\mathrm{cm})^{\mathrm{y}}\end{array}$ & $\begin{array}{c}2005 \\
\text { yield } / \mathrm{TCSA}^{\mathrm{x}} \\
\left(\mathrm{kg} \cdot \mathrm{cm}^{-2}\right)\end{array}$ & $\begin{array}{c}2006 \\
\text { bloom/TCSA } \\
\text { (flower clusters } / \mathrm{cm}^{2} \text { ) }\end{array}$ & $\begin{array}{l}2006 \text { harvested } \\
\text { fruits/TCSA } \\
\left(\text { fruit } / \mathrm{cm}^{2}\right)\end{array}$ & $\begin{array}{c}2006 \\
\text { yield } / \mathrm{TCSA}^{\mathrm{x}} \\
\left(\mathrm{kg} \cdot \mathrm{cm}^{-2}\right)\end{array}$ \\
\hline Unsprayed, 100 & 21.7 & 0.8 & 1.6 & 0.9 & 0.2 \\
\hline Unsprayed, 50 & 22.2 & 0.6 & 2.7 & 1.7 & 0.3 \\
\hline Unsprayed, 0 & 21.5 & 0.0 & 3.9 & 2.9 & 0.5 \\
\hline Sprayed, 100 & 26.3 & 0.5 & 0.2 & 0.1 & 0.0 \\
\hline Sprayed, 50 & 27.5 & 0.6 & 0.1 & 0.2 & 0.0 \\
\hline Sprayed, 0 & 26.9 & 0.0 & 0.7 & 0.8 & 0.2 \\
\hline \multicolumn{6}{|l|}{ Significance } \\
\hline \multicolumn{6}{|l|}{$\mathrm{GA}_{4}+7^{\mathrm{w}}$} \\
\hline Unsprayed & $21.8 \mathrm{~b}$ & $0.4 \mathrm{NS}$ & $2.7 \mathrm{a}$ & $1.9 \mathrm{a}$ & $0.3 \mathrm{a}$ \\
\hline Sprayed & $26.9 \mathrm{a}$ & 0.4 & $0.3 \mathrm{~b}$ & $0.4 \mathrm{~b}$ & $0.1 \mathrm{~b}$ \\
\hline$P$ values & $<0.0001$ & 0.09 & $<0.0001$ & 0.0001 & 0.0001 \\
\hline \multicolumn{6}{|l|}{ Crop load ${ }^{\mathrm{v}}$} \\
\hline $\mathrm{L}$ & NS & $* * * *$ & $* *$ & $* *$ & $* *$ \\
\hline Q & NS & $* * * *$ & NS & NS & NS \\
\hline Model $r^{2}$ & 0.53 & 0.86 & 0.71 & 0.63 & 0.65 \\
\hline
\end{tabular}

${ }^{2}$ Treatments are listed by application status (unsprayed or sprayed) and manually adjusted crop level (100\%, 50\%, or $0 \%$ crop). All interactive terms not significantly different $(P=0.05)$.

${ }^{y}$ Mean of 10 terminal shoots per tree.

${ }^{x}$ Trunk cross-sectional area.

wAnalysis by factorial analysis of variance and means separation by Tukey's Studentized range test $(P=$ $0.05)$. Means followed by the same letter are not statistically significant within a column.

${ }^{v} \mathrm{~L}=$ linear effect; $\mathrm{Q}=$ second-order (quadratic) effect.

Ns, $* *, * * *$ Nonsignificant or significant at $P=0.01$ or 0.0001 , respectively.

Table 6. Effects of spray concentration and crop load on response to ethephon application at $45 \mathrm{~d}$ after full bloom in 2004 in severely alternating 'Cameo'/B.9 apple trees. ${ }^{\text {. }}$

\begin{tabular}{|c|c|c|c|c|c|}
\hline Treatment & $\begin{array}{l}2004 \text { shoot } \\
\text { extension } \\
(\mathrm{cm})^{\mathrm{y}}\end{array}$ & $\begin{array}{c}2004 \\
\text { yield } / \mathrm{TCSA}^{\mathrm{x}} \\
\left(\mathrm{kg} \cdot \mathrm{cm}^{-2}\right)\end{array}$ & $\begin{array}{c}2005 \\
\text { bloom } / \mathrm{TCSA} \\
\text { (flower clusters } / \mathrm{cm}^{2} \text { ) }\end{array}$ & $\begin{array}{l}2005 \text { harvested } \\
\text { fruits } / \mathrm{TCSA}^{\mathrm{x}} \\
\left(\text { fruit } / \mathrm{cm}^{2}\right)\end{array}$ & $\begin{array}{c}2005 \\
\text { yield } / \mathrm{TCSA}^{\mathrm{x}} \\
\left(\mathrm{kg} \cdot \mathrm{cm}^{-2}\right)\end{array}$ \\
\hline 0,100 & 30.0 & 1.2 & 0.2 & 0.7 & 0.1 \\
\hline 0,50 & 31.7 & 1.0 & 1.7 & 3.6 & 0.8 \\
\hline 0,0 & 32.1 & 0.0 & 7.1 & 5.9 & 0.9 \\
\hline 300,100 & 28.7 & 1.1 & 0.7 & 1.2 & 0.2 \\
\hline 300,50 & 27.3 & 1.1 & 2.8 & 4.7 & 0.8 \\
\hline 300,0 & 30.2 & 0.0 & 7.7 & 6.1 & 0.9 \\
\hline 600,100 & 28.4 & 1.2 & 1.7 & 3.8 & 0.6 \\
\hline 600,50 & 28.1 & 1.1 & 4.4 & 5.7 & 0.9 \\
\hline 600,0 & 23.5 & 0.0 & 7.8 & 8.6 & 1.1 \\
\hline 900,100 & 24.6 & 0.9 & 1.8 & 3.5 & 0.6 \\
\hline 900,50 & 24.2 & 0.9 & 5.3 & 7.0 & 1.1 \\
\hline 900,0 & 27.0 & 0.0 & 6.3 & 7.7 & 1.0 \\
\hline
\end{tabular}

Significance

Crop load ${ }^{\mathrm{w}}$

\begin{tabular}{|c|c|c|c|c|c|}
\hline \\
\hline $\mathrm{L}$ & NS & $* * * *$ & $* * * *$ & $* * * *$ & $* * * *$ \\
\hline Q & NS & $* * * *$ & NS & NS & $* *$ \\
\hline \multicolumn{6}{|c|}{ Ethephon concentration $^{\mathrm{w}}$} \\
\hline $\mathrm{L}$ & $* *$ & NS & $*$ & $* * * *$ & $* * *$ \\
\hline Q & NS & NS & NS & NS & NS \\
\hline \multicolumn{6}{|c|}{ Interaction $^{\mathrm{w}}$} \\
\hline $\mathrm{C}^{*} \mathrm{E}$ & NS & NS & NS & NS & 0.07 \\
\hline $\mathrm{C}^{*} \mathrm{C}^{*} \mathrm{E}$ & NS & NS & $*$ & NS & NS \\
\hline $\mathrm{C}^{*} \mathrm{E}^{*} \mathrm{E}$ & NS & NS & NS & NS & NS \\
\hline Model $r^{2}$ & 0.33 & 0.87 & 0.71 & 0.71 & 0.67 \\
\hline
\end{tabular}

${ }^{\mathrm{z}}$ Treatments are listed by spray concentration $(\mathrm{mg} / \mathrm{L})$ and manually adjusted crop level $(100 \%, 50 \%$, or $0 \%$ crop).

${ }^{\mathrm{y}}$ Mean of 10 terminal shoots per tree.

${ }^{\mathrm{x}}$ Trunk cross-sectional area.

${ }^{\mathrm{w}} \mathrm{L}=$ linear effect; $\mathrm{Q}=$ second-order (quadratic) effect; $\mathrm{C}=$ crop load; $\mathrm{E}=$ ethephon.

$\mathrm{NS}, *, * *, * * *, * * * *$ Nonsignificant or significant at $P=0.05,0.01,0.001$, or 0.0001 , respectively.

manual crop reduction in the biennial block suggest greater receptivity to horticultural interventions, which might encourage flowering and mitigate the amplitude of alternation.
Throughout all six trials, the strongest proportional floral initiation effects from bioregulators were seen at the $50 \%$ crop level. In biennial trial sites, i.e., 2004 'Cameo' and 
Table 7. Effects of spray concentration and crop load on response to ethephon application at $45 \mathrm{~d}$ after full bloom in 2005 in annually cropping 'Cameo'/Nic.29 apple trees. ${ }^{\mathrm{z}}$

\begin{tabular}{|c|c|c|c|c|c|}
\hline Treatment & $\begin{array}{l}2005 \text { shoot } \\
\text { extension } \\
(\mathrm{cm})^{\mathrm{y}}\end{array}$ & $\begin{array}{c}2005 \\
\text { yield } / \mathrm{TCSA}^{\mathrm{x}} \\
\left(\mathrm{kg} \cdot \mathrm{cm}^{-2}\right)\end{array}$ & $\begin{array}{c}2006 \\
\text { bloom/TCSA } \\
\text { (flower clusters } / \mathrm{cm}^{2} \text { ) }\end{array}$ & $\begin{array}{l}2006 \text { harvested } \\
\text { fruits } / \mathrm{TCSA}^{\mathrm{x}} \\
\left(\text { fruit } / \mathrm{cm}^{2}\right)\end{array}$ & $\begin{array}{c}2006 \\
\text { yield/TCSA } \\
\left(\mathrm{kg} \cdot \mathrm{cm}^{-2}\right)\end{array}$ \\
\hline$\overline{0,100}$ & 10.4 & 1.3 & 6.3 & 5.1 & 1.0 \\
\hline 0,50 & 11.7 & 1.1 & 8.8 & 6.3 & 1.3 \\
\hline 0,0 & 10.5 & 0.0 & 11.6 & 7.3 & 1.5 \\
\hline 300,100 & 11.3 & 1.4 & 7.9 & 6.4 & 1.4 \\
\hline 300,50 & 11.7 & 1.2 & 7.6 & 5.1 & 1.1 \\
\hline 300,0 & 10.1 & 0.0 & 14.6 & 8.2 & 1.6 \\
\hline 600,100 & 10.2 & 1.1 & 8.5 & 5.5 & 1.2 \\
\hline 600,50 & 10.3 & 1.1 & 10.2 & 5.8 & 1.2 \\
\hline 600,0 & 11.7 & 0.0 & 12.7 & 7.2 & 1.4 \\
\hline 900,100 & 10.1 & 1.0 & 8.7 & 5.9 & 1.2 \\
\hline 900,50 & 9.7 & 1.1 & 9.9 & 6.5 & 1.3 \\
\hline 900,0 & 9.6 & 0.0 & 14.8 & 7.9 & 1.5 \\
\hline \multicolumn{6}{|c|}{ Significance } \\
\hline \multicolumn{6}{|l|}{ Crop load ${ }^{\mathrm{w}}$} \\
\hline $\mathrm{L}$ & NS & $* * * *$ & $*$ & * & ** \\
\hline Q & NS & $* * * *$ & NS & NS & NS \\
\hline \multicolumn{6}{|c|}{ Ethephon concentration ${ }^{w}$} \\
\hline $\mathrm{L}$ & NS & NS & NS & NS & NS \\
\hline Q & NS & NS & NS & NS & NS \\
\hline Model $r^{2}$ & 0.21 & 0.90 & 0.61 & 0.47 & 0.42 \\
\hline
\end{tabular}

${ }^{z}$ Treatments are listed by spray concentration $\left(\mathrm{mg} \cdot \mathrm{L}^{-1}\right)$ and manually adjusted crop level $(100 \%, 50 \%$, or $0 \%$ crop $)$. All interactive terms not significantly different $(P=0.05)$.

${ }^{y}$ Mean of 10 terminal shoots per tree.

${ }^{x}$ Trunk cross-sectional area.

${ }^{\mathrm{w}} \mathrm{L}=$ linear effect; $\mathrm{Q}=$ second-order (quadratic) effect; $\mathrm{C}=$ crop load; $\mathrm{E}=$ ethephon.

Ns, *,**, ***,****Nonsignificant or significant at $P=0.05,0.01,0.001$, or 0.0001 , respectively.

'Honeycrisp', the baseline levels for return bloom were extremely low, leaving little margin to observe additional floral inhibition from application of GA. Conversely, where baseline levels of return bloom were relatively high, i.e., decropped 2005 'Cameo', little margin remained to observe increased return bloom resulting from ethephon application. In simple terms, it is difficult to further reduce flowering on blank trees or to increase flowering if virtually all spurs are already reproductive.

In the 2004 'Cameo' trial, $\mathrm{GA}_{4+7}$ showed greater effects at $10 \mathrm{~mm}$ and $20 \mathrm{~mm}$ than at petal fall. Results from the 2005 'Cameo' trial were more similar to concurrent timing studies with $\mathrm{GA}_{4}$ in 'Fuji' (Schmidt, 2006), which suggested that earlier application, i.e., petal fall, provided greater floral inhibition. Results at $10-\mathrm{mm}$ fruitlet size were good in all trials, and those seeking to reduce spray concentrations while maintaining efficacy might be well served to "aim for the middle" and apply GA at that timing.

Ethephon increased flowering in cases in which poor return bloom was expected (less than two flower clusters $/ \mathrm{cm}^{2}$ TCSA) such as trees carrying full or half crops in the 2004 trial; floral initiation was increasingly promoted by higher concentrations of ethephon. Spray effects were largely nonexistent, however, in decropped trees from 2004 or all trees in the 2005 trial, in which baseline levels of return bloom were relatively high (greater than six flower clusters $/ \mathrm{cm}^{2}$ TCSA). These trends imply that commercial applications of ethephon to improve return bloom might be relatively ineffective in orchards with reason- able balance between vegetative and reproductive growth.

Although blossom pruning eliminated half the available fruiting sites for the $50 \%$ crop treatments, yields in the year of treatment were similar to the unpruned $100 \%$ treatments (Tables 1, 3, 4, 5, 6, and 7) attributable primarily to enhanced fruit set in blossom-pruned trees (data not shown). Despite the apparent diminished resolution between crop levels, treatment effects remained clear in terms of the following season's return bloom and yields, suggesting that factors associated with the presence or absence of flowers are at least as important to subsequent floral initiation as those associated with fruit set and seed development.

In all trials, partial or complete removal of flowers in one season dramatically promoted flower bud differentiation as evidenced by increased cropping in the next season. The diminution or elimination of endogenous gibberellins produced in developing fruits is likely a primary contributor to these effects but alone does not explain all of our results. The relative lack of sensitivity to exogenous GA in artificially decropped trees in the two sites with greatest background levels of alternation (2004 'Cameo' and 'Honeycrisp') either suggests a more complex model of floral initiation or lack of spray material efficacy. The latter explanation is unlikely, however, because the same spray programs showed clear efficacy in trees with $50 \%$ crops. Overall, the biennial 'Cameo' orchard, entering its off-year, was more sensitive to the floral promotion effects of ethephon and less sensitive to the floral inhibition effects of
GA than was the more annual 'Cameo' site. In simple terms, it was relatively easier to increase flowering in trees destined for light bloom and to decrease flowering in trees destined for moderate bloom, although experimental interventions were identical in each case. These tendencies suggest a predilection of presumably undifferentiated buds to a certain fate before the effects of developing fruits or applications of exogenous bioregulators could be imposed on them. In short, our results support a complex model of floral initiation in apple influenced, but not controlled, by the presence of seed-derived gibberellins.

Flowering in apple is a complex and still poorly understood process; it is unclear how specific these results are to these particular cultivars, growing seasons, and ambient conditions in the Pacific Northwest. Similar studies in other cultivars and regions would likely improve our understanding of apple floral initiation and the role of crop load on bioregulator efficacy.

\section{Literature Cited}

Beach, S.A. 1903. Thinning apples. N.Y. Agr. Expt. Sta. Bul. 239.

Bertelsen, M.G. and D.S. Tustin. 2002. Suppression of flower bud formation in light cropping trees of 'Pacific Rose' apple using gibberellin sprays. J. Hort. Sci. Biotechnol. 77:753757.

Bowman, F.T. 1932. Alternate cropping of apples: Its effect upon the industry in New South Wales. Agr. Gaz. New South Wales October: 777-781.

Byers, R.E. 1993. Controlling growth of bearing apple trees with ethephon. HortScience 28: 1103-1105.

Byers, R.E. and D.H. Carbaugh. 1991. Effect of chemical thinning sprays on apple fruit set. HortTechnology 1:41-48.

Callejas, R. and F. Bangerth. 1997. Is auxin transport of apple fruit an alternative signal for inhibition of flower bud induction? Acta Hort. 463:271-277.

Carne, W.M. 1931. Heavy and light cropping in alternate years: A serious defect of the Australian apple industry. J. Council Scientific Ind. Res. 4:65-77.

Chan, B.G. and J.C. Cain. 1967. The effect of seed formation on subsequent flowering in apple. Proc. Amer. Soc. Hort. Sci. 91:63-68.

Dennis, F.G., Jr. and J.C. Neilsen. 1999. Physiological factors affecting biennial bearing in tree fruit: The role of seeds in apple. HortTechnology 9:317-322.

Elfving, D.C. 1996. Physiological processes and the coordination of vegetative and reproductive plant growth and development, p. 3-10. In: Maib, K., P. Andrews, G. Lang and K. Mullinix (eds.). Tree fruit physiology: Growth and development. Good Fruit Grower, Yakima, WA.

Ferree, D.C. and J.C. Schmid. 2000. Chemical thinning of 'Fuji' apple in the Midwest. J. Amer. Pomol. Soc. 54:61-67.

Greene, D.W. 1989. Gibberellins $A_{4+7}$ influence fruit set, fruit quality, and return bloom of apples. J. Amer. Soc. Hort. Sci. 114:619-625.

Greene, D.W. 1996. Ethylene-based preharvest growth regulators, p. 149-159. In: Maib, K., P. Andrews, G. Lang and K. Mullinix (eds.). Tree fruit physiology: Growth and development. Good Fruit Grower, Yakima, WA 
Harley, C.P., H.H. Moon, and L.O. Regeimbal. 1958. Evidence that post-bloom apple-thinning sprays of naphthaleneacetic acid increase blossom-bud formation. Proc. Amer. Soc. Hort. Sci. 72:52-56.

Harley, C.P. and L.O. Regeimbal. 1959. Comparative effectiveness of naphthaleneacetic acid and naphthylacetamide sprays for fruit thinning York Imperial apples and initiating blossom buds on Delicious apple trees. Proc. Amer. Soc. Hort. Sci. 74:64-66.

Karaszewska, A., B. Jankowska, M. Mika, and M.J. Grochowska. 1986. Effects of growth regulator treatments on the hormone pattern in the trunk and the collar tissue of apple trees. Acta Hort. 179:185-194.

Luckwill, L.C. and R.D. Child. 1978. Part tree [sic] thinning of apples with CEPA. Acta Hort. 80: 271-274.

Marino, F. and D.W. Greene. 1981. Involvement of gibberellins in the biennial bearing of 'Early
McIntosh' apples. J. Amer. Soc. Hort. Sci. 106: 593-596.

McArtney, S.J. 1994. Exogenous gibberellin affects biennial bearing and the fruit shape of 'Braeburn' apple. N. Z. J. Crop Hort. Sci. 22:343-346.

Meador, D.B. and B.H. Taylor. 1987. Effect of early season foliar sprays of $\mathrm{GA}_{4+7}$ on russeting and return bloom of 'Golden Delicious' apple. HortScience 22:412-415.

Palmer, R.C. and D.V. Fischer. 1937. Apple thinning investigations: Summerland experimental station 1920-1935. Tech. Bul. Can. Dept. Agr. 10:5-27.

Ramirez, H. 1995. Estimation and identification of apple seed gibberellins in the early stages of fruit development. Acta Hort. 394:101-103.

Schmidt, T. 2006. Manipulation of crop load with bioregulators to mitigate biennial bearing in apple. Master's thesis, Wash. State Univ., Pullman, WA.

Stephan, M., F. Bangerth, and G. Schneider. 1999. Quantification of endogenous gibberellins in exudates from fruits of Malus domestica. Plant Growth Regulat. 22:55-58.

Stephan, M., F. Bangerth, and G. Schneider. 2001. Transport and metabolism of exogenously applied gibberellins to Malus domestica Borkh cv. Jonagold. Plant Growth Regulat. 33:77-85.

Tromp, J. 1982. Flower-bud formation in apple as affected by various gibberellins. J. Hort. Sci. 57:277-282.

Walsh, C.S. and W.J. Kender. 1982. Effect of cultivar, strain, and growth regulator treatments on shoot development and ethylene evolution in apple trees. J. Amer. Soc. Hort. Sci. 107:198202.

Washington State University. 2009. 2009 crop protection guide for tree fruits in Washington. Wash. State Univ. Ext. Bul. EB0419.

Weinbaum, S.A., T.M. DeJong, and J. Maki. 2001. Reassessment of seed influence on return bloom and fruit growth in 'Bartlett' pear. HortScience 36:295-297. 